\title{
Relationship between Salivary Flow Rates and the Amount of Candida in Saliva in Smokers
}

\author{
Surya Nelis \\ Department of Oral Medicine \\ Faculty of Dentistry, Universitas Andalas \\ Padang, Indonesia \\ nelis9surya@gmail.com
}

\begin{abstract}
Smoking is one of the predisposing factors for oral candidiasis. The mechanism is possibly caused by chemical substances in cigarettes that can provide nutritionS for candida, local changes in epithelium that which leads to candida colonization, decreased antibodies in saliva and decreased salivary flow rates. The objective of this study was to investigate the relationship between salivary flow rates and the amount of Candida in smoker's saliva. This research was an observational analytic with cross sectional design. The samples consist of 40 healthy smokers with age range between 20-45 years. The method used to collect unstimulated salivary is spitting method. Quantity of candida is counted using colony counter and ISO 7218 formula. Data was analyzed by Anova and Pearson correlation. The result showed that the difference of average candida in every group of salivary flow rates was not significant $(\mathrm{p}=\mathbf{0 . 8 5 2})$. Pearson correlation analysis confirmed that correlation were in the weak category (close to 0 ) with value of significance 0.308 . As conclusion, salivary flow rates didn't have significant effect toward amount of candida in the smoker's saliva.
\end{abstract} health

Keywords-salivary flow rate, candida, smoking, oral

\section{INTRODUCTION}

Smoking gave adverse effect on the health of the body, including the oral health $[1,2]$. The oral cavity is the main entrance of toxic substances from cigarettes, whereas saliva is the main biological fluid exposed to cigarette smoke that contains various toxic substances who responsible for structural and functional changes in saliva [3]. Long-term smoking will change salivary flow rates and salivary $\mathrm{Ph}[3,4]$. Decreased salivary flow rates may affect the oral cavity homeostasis process [3,4,5].

Saliva is a complex body fluid and essential for oral health. Saliva serves for digestion, protection (viruses, fungi, and bacteria), taste sensation, protecting the oral mucosa, $\mathrm{pH}$ balance, and tooth remineralization $[3,6]$. Changes in salivary flow rates have an important role in the pathogenesis of dental and oral diseases [3,7].

A decrease in the immune system is a major predisposing factor that increases the incidence of candidiasis [8,9]. Oral candidiasis cases also occur in healthy people with decreased immune response that caused by several factors such as endocrine disorders, malnutrition, poor oral hygiene, and heavy smokers
[10]. Bouquot and Schroeder (1992) said that most patients $(83 \%)$ with average oral candidiasis are intermediate and heavy smokers [11].

Candida is a normal component of the oral cavity that can be affected by cigarettes so that it changes the amount of candida itself [8]. The amount of candida colonies in saliva can serve as an indicator to identify the prevalence of candida. The prevalence of candida in smokers (average $104 \mathrm{CFU} / \mathrm{ml}$ ) was higher than nonsmokers (average $50 \mathrm{CFU} / \mathrm{ml}$ ) [12]. Local risk factors that associated with increased prevalence of oral candidiasis and carrier were xerostomia, smoking, wearing denture, and poor oral hygiene [13,14]. Soysa and Ellepola (2005) states that smoking, whether combined with other factors or not, may be an important predisposing factor in oral candidiasis, although its pathogenesis is not known with certainty $[12,15]$. Smoking can increase the number of candida significantly from $30 \%$ to $70 \%$ [16].

Decreasing of salivary flow rates related to increasing the amount of candida [17-20]. Research done by Navazesh et al (1995) showed relation that inversely proportional between salivary flow rate and amount of candida in saliva $[21,22]$. The research done by Torrest et al (2002) also proved that subject with low salivary flow rate has higher amount of candida [23]. The objective of this study was to investigate the relationship between salivary flow rate and the amount of candida in smoker's saliva.

\section{MATERIALS AND METHODS}

This research was an observational analytic with cross sectional design. The samples consist of 40 healthy men smokers were selected using random sampling with the criteria were the age range 20-45 years, with smoking duration minimum is more than 5 years, and number of cigarettes smoked more than 8 cigarettes a day, didn't consume any medicine in the near future, and willingly to participate in the study by filling the informed consent. Unstimulated saliva was taken at 9 to 11 o'clock (GMT+7 hours) used spitting method, and samples didn't consume any food or drinks 1 hour before salivary taking. Salivary flow rates criteria are divided to hyposalivation (less than $0,1 \mathrm{ml} / \mathrm{min})$, low $(0.1-0.3 \mathrm{ml} / \mathrm{min})$, normal $(0.3-$ $0.5 \mathrm{ml} / \mathrm{min}$ ) and hypersalivation (more than $0.5 \mathrm{ml} / \mathrm{min}$ ). 
Quantity of candida is counted using colony counter and ISO 7218 formula. Data was analyzed by Anova and Pearson correlation. Ethical clearance was obtained from the Research Ethics Committees of Faculty of Medicine, Universitas Andalas.

\section{RESULTS}

The subject's age in this research was 20 to 33 years. The majority of salivary flow rates in subjects were low, 7 subjects had hypersalivation, and none of the subjects suffered from hyposalivation. The amount of candida colonies in saliva range between 0 to 373 $\mathrm{CFU} / \mathrm{ml}$ with the average of $196.38 \mathrm{CFU} / \mathrm{ml}$. Overall, the 40 subjects have homogeneous variants. Based on salivary flow rates, obtained that the highest average amount of candida is found on the low salivary flow rates, which is $204.33 \mathrm{CFU} / \mathrm{ml}$. As to the lowest amount of candida is found on the normal salivary flow rates, which is $184.98 \mathrm{CFU} / \mathrm{ml}$ (Table I).

TABLE I. DISTRIBUTION OF AMOUNT OF CANDIDA IN SALIVA BASED ON SALIVARY RATES

\begin{tabular}{|l|c|c|c|c|c|c|}
\hline \multirow{2}{*}{$\begin{array}{c}\text { Salivary Flow } \\
\text { Rates }\end{array}$} & \multirow{N}{*}{$\mathbf{N}$} & \multicolumn{2}{c|}{$\begin{array}{c}\text { Amount of } \\
\text { Candida (CFU/ml) }\end{array}$} & $\begin{array}{c}\text { Std. } \\
\text { Error }\end{array}$ & \multirow{2}{*}{ Min } & \multirow{2}{*}{ Max } \\
\cline { 3 - 5 } & & Mean & SD & & & \\
\hline Low & 21 & 204.33 & 95.842 & 20.914 & 0 & 327 \\
\hline Normal & 12 & 184.92 & 95.787 & 27.651 & 18 & 373 \\
\hline Hypersalivation & 7 & 192.14 & 103.538 & 39.134 & 0 & 336 \\
\hline Total & 40 & 196.38 & 95.002 & 15.021 & 0 & 373 \\
\hline
\end{tabular}

Statistical test using Analysis of Variance, showed that the difference between the average amount of candida in each category of salivary flow rates (low, normal, and hypersalivation) was not significant $(\mathrm{p}=0.852)$ (Table II).

TABLE II. ANOVA TEST OF MEAN DIFFERENCE OF THE AMOUNT OF CANDIDA IN EVERY GROUPS OF SALIVARY FLOW RATES (LOW, NORMAL, AND HYPERSALIVATION)

\begin{tabular}{|l|c|c|c|c|c|}
\hline & $\begin{array}{c}\text { Sum of } \\
\text { Squares }\end{array}$ & Df & $\begin{array}{c}\text { Mean } \\
\text { Square }\end{array}$ & F & Sig. \\
\hline Between Groups & 3030.935 & 2 & 1515.467 & \multirow{2}{*}{.161} & .852 \\
\hline Within Groups & 348960.4 & 37 & 9431.363 & & \\
\hline Total & 351991.4 & 39 & & & \\
\hline
\end{tabular}

Pearson Correlation Analysis confirmed that negative correlation (-0.1650) between candida $(\mathrm{CFU} / \mathrm{ml})$ with salivary flow rates $(\mathrm{ml} /$ minute) are in the low category (close to 0 ), with significance value of 0.308 , showed that the correlation is not significant (Table III).

TABLE III. CORRELATION ANALYSIS BETWEEN AMOUNT OF CANDIDA IN SALIVA AND SALIVARY FLOW RATES

\begin{tabular}{|l|l|r|r|}
\hline \multicolumn{2}{|c|}{} & $\begin{array}{c}\text { Amount of } \\
\text { Candida } \\
\text { (CFU/ml) }\end{array}$ & $\begin{array}{c}\text { Flow Rate } \\
\text { (ml/Minute) }\end{array}$ \\
\hline $\begin{array}{l}\text { Number of } \\
\text { Candida }\end{array}$ & Pearson Correlation & 1 &,- 165 \\
(CFU/ml) & Sig. (2-tailed) & &, 308 \\
\hline $\begin{array}{l}\text { Salivary } \\
\text { Flow Rate }\end{array}$ & Pearson Correlation & 40 & 40 \\
(ml/Min) & Sig. (2-tailed) &,- 165 & 1 \\
& N &, 308 & 40 \\
\hline
\end{tabular}

\section{DISCUSSION}

Smoking is associated with a variety of changes in the oral cavity. Long term of smoking will change salivary flow rates and $\mathrm{pH}$ of saliva $[2,6,15,24,25]$. The change of salivary flow rates has important role in pathogenesis of candidiasis [17,21,22]. Smoking also causes decreasing the antibody in saliva, and affects the amount of microorganism in saliva. Smoking is one of the predisposition factors that are important in increasing the amount of candida in saliva $[2,4,7,23,26]$.

Result of this study showed that the majority of subjects have low salivary flow rates. This result was in accordance with Mala et al. research in 2016 which stated that the mean of salivary flow rates in smokers is lower than non-smokers [3]. Seven subjects had hypersalivation were subjects with smoking duration less than 10 years and the number of cigarettes smoked less than 8 cigarettes a day. Salivary flow rates changes depending on the duration and number of cigarettes smoked [24,27,28]. This is related to nicotine concentrate in cigarettes. Even though, at first nicotine increase salivary flow rates, by doses up it will decrease the flow rates [3,24,27].

Saliva is a complex and important body fluid which is very essential for oral health [24]. The quality, quantities, and elements contained play an important role in the modulation of the candida population [16]. The continuous movement of saliva results in candida cells ingested with saliva and out of the oral cavity $[29,30]$. Decreasing of salivary flow rates and the absence of antifungal in saliva such as lactoferrine and lysozyme may increase the number of candida in the oral cavity [16].

Statistical test in this research on salivary candida showed that the difference of average candida in every group of salivary flow rates was not significant, and has a weak correlation. This result are different from the previous studies that were carried out by Navazesh (1995) and Torres et al (2002) which stated that decreased of salivary flow rates has been associated with increased oral carriage rates of candida. This is likely due to different samples, where in previous research was done on subjects with xerostomia, and the population studied had underlying diseases. Smoking is one of the predisposing factors for an increase in the number of candida in the oral cavity $[9,11,12,15,28]$. There are several factors responsible for the increase in the amount of candida in smoker's saliva other than hyposalivation $[12,15,23,31]$.

Mechanism of oral candidiasis in smokers is not yet known for certain. This mechanism is possibly caused by chemical substances in cigarettes that can provide nutrition for candida, local changes in epithelium that which leads to candida colonization [12,14,16], decreased antibodies in saliva and hyposalivation $[8,24,32,33]$. Duration and amount of smoking would have a different impact on number of the candida colonies [12].

As a conclusion in this research, the decreased of the salivary flow rates in smokers has no significant 
effect on the increase of the amount of candida in saliva. This study has some limitations. The number of sample may be too small, and candida was examined without separating the different candida species.

\section{ACKNOWLEDGMENT}

We thank Roni Fitarsa and Lisma Yendri for your support and SMF Microbiology Laboratory of Muhammad Djamil Hospital for laboratory support.

\section{REFERENCES}

[1] J. Prabhat, P. Richard, "Global effect of smoking, of quitting and of taxing tobacco," The New Eng. J. of Med., vol. 370, pp. 60-68, 2014.

[2] N.W. Johnson, C.A. Bain, "Tobacco and oral disease," Brit. Dent. J., vol. 189(4), 2000.

[3] M. Singh, N.A. Ingle, N. Kaur, P. Yadav, E. Ingle, "Effect long term smoking on salivary flow rate and salivary $\mathrm{pH}$," Indian Ass. of Pub. Health. Dent., vol. 13(1), 2016.

[4] J.K. Ghulam, J. Muhammad, I. Muhammad, "Effect of smoking on salivary flow rate," Gomal. J. of Med. Sciences, vol. 8(2), pp. 221-224, 2010

[5] V.Z. Fenol-Palomeres, et al., "Unstimulated salivary flow rate, $\mathrm{pH}$ and buffer capacity of saliva in healthy volunteer," Rev. Esp. Enferm. DIG, vol. 6(11), pp. 772-783, 2004.

[6] M. Rad, S. Kakoie, F.N. Brojeni, N. Pourdamghan, "Effect long-term smoking on whole mouth salivary flow rate and oral health," JDDD, vol. 49(4), 2010

[7] I.D. Mandel, "The diagnostic use of saliva," J. Oral Pathol. Med., vol. 19, pp. 119-125, 1990.

[8] S.W. John, Clinical microbiology and infectious disease, $2^{\text {nd }}$ ed., Edinburgh: Churchill Livingstone Elsevier, 2008, pp. 18-32.

[9] Greenberg, S. Martin, M. Glick, Burket's oral medicine: diagnosis and treatment, $10^{\text {th }}$ ed., Spain; BC Decker Inc., 2003, pp. $49-50$

[10] P.K. Rao, "Oral candidiasis-A review," Biol. and Biomed. Reports, vol. 2(2), pp. 110-114, 2012

[11] J. Bouquot, K. Schroeder K, "Oral effects of tobacco abuse," J. of The American Dent. Inst. for Cont. Edu., vol. 43, pp. 4-17, 1992.

[12] T. Becker, D. Porat, M. Gorsky. "The association between smoking habits and candida in the oral cavity, Int. J. Dent. Oral Health, vol. 12, 2015.

[13] K, Kamikawa, K. Sugihara, "In vitro and in vivo removal of oral candida from the denture base," Gerodontology, 2014.

[14] R. Calcaterra, et al., "Occurrence of candida species colonization in a population of denture-wearing immigrants. Int. J. of Immunopathol. and Pharmacol., vol. 26, pp. 239-246, 2013.

[15] N.S. Soysa, A. Ellepola, "The impact of cigarette/tobacco smoking on oral candidosis: an overview," Oral Dis., vol. 11, pp. 268-273, 2005

[16] C. Scully, M. El-kabir, L.P. Samaranayake, "Candida and oral candidosis," Crit. Rev. Ord. Biol. Med., vol. 5(2), pp. 125-157, 1994.

[17] M. Navazesh, G. Wood, V.J. Brightman, "Relationship between salivary flow rates and Candida albicans counts," Oral Surg. Oral Med. Oral Pathol. Oral Radiol. Endod., vol. 80, pp. 284-288, 1995.

[18] R.D. Cannon, A.R. Holmes, A.B. Mason, B.C. Monk, "Oral candida: clearance, colonization or candidiasis?" J. Dent. Res., vol. 74, pp. 1152-1161, 1995 .

[19] A.O.C. Jorge, M.A.G. Totti, O.P. Almeida, C. Scully, "The effect of sialoadenectomy on the carriage of Candida albicans in the mouths of rats," J. Oral Pathol. Med., vol. 22, pp. 138-140, 1993.

[20] M.A.G Totti, A.O.C Jorge, E.B. Santos, O.P. Almeida, C. Scully, "Implantation of Candida albicans and other candida species in the oral cavity of rats," J. Oral Pathol. Med., vol. 25, pp. 308-310, 1996

[21] J.B. Epstein, N.N. Pearsall, E.L. Truelove, "Quantitative relationship between Candida albicans and the clinical status of human subjects," J. Clin. Microbiol., vol. 12, pp. 475-476, 1980.
[22] A.O.C. Jorge, M.A.G Totti, O.P. Almeida, C. Scully, "Oral candidiasis established in the sialoadenectomised rat," J. Oral Pathol. Med., vol. 22, pp. 54-56, 1993.

[23] S.R. Torres, et al., "Relationship between salivary flow rates and candida counts in subjects with xerostomia," Oral Surg. Oral Med. Oral Pathol. Oral Radiol. and Endodont., March 2002.

[24] R. Maryam, et al., "Effect of long-term smoking on wholemouth salivary flow rate and oral health," J. Dent. Res. Dent. Clin. Dent. Prospect, vol. 4(4), pp. 110-114, 2010.

[25] S. Dyasanoor, S.C. Saddu, "Association of xerostomia and assessment of salivary flow using modified Schirmer test among smokers and healthy individuals: A preliminutesary study," J. of Clin. and Diag. Res., vol. 8(1), pp. 211-213, 2014.

[26] P.C. Fox, J.A. Ship, Salivary gland diseases. In: M.S Greenberg, S. Glick, eds., Burket's oral medicine: Diagnosis and treatment, $11^{\text {th }}$ ed., Hamilton: BC Decker, 2008, pp. 191223.

[27] A.R.P. Kusuma, "Pengaruh merokok terhadap kesehatan gigi dan rongga mulut, Majalah Sultan Agung.

[28] S. Wikner, P.O. Söder, "Factors associated with salivary buffering capacity in young adults in Stockholm, Sweden," Scand. J. Dent. Res., vol. 102, pp. 50-53, 1994.

[29] R.D. Cannon, W.L. Chaffin, "Oral colonization by Candida albicans," Crit. Rev. Oral Boil. Med., vol. 10(3), pp. 359-383, 1999.

[30] J. Hannula, Clonal types of oral yeasts in relation to age, health and geography, Dissertation, Finland. Inst. of Dent. Dept. of Perio., Univ. of Helsinki, 2000.

[31] A.M.G. Darwazeh, Z.N. Al-Dwairi, A.S. Al-Zawahiri, "The relationship between tobacco smoking and oral colonization with candida species," The J. of Cont. Dent. Prac., vol. 11(3), 2010

[32] A. Pejcic, R. Obradovic, L. Kesic, D. Kojovic, "Smoking and periodontal disease: A review," Med. and Biol., vol. 14(2), pp. 53-59, 2007.

[33] D.F. Kinane, M. Radvar, "The effect of smoking on mechanical and antimicrobial periodontal therapy," J. Period., vol. 68, pp. 467-472, 1997 